\title{
Life history traits and fishing mortality estimations of Caspian vimba, Vimba vimba (L.), in southwestern coastal regions of the Caspian Sea
}

\author{
Fateme Taridashti, Javid Imanpour, Shahram Abdolmalaki, Mahvash Hadavi
}

Received - 11 November 2016/Accepted - 06 August 2017. Published online: 30 September 2017; @Inland Fisheries Institute in Olsztyn, Poland Citation: Taridashti F., Imanpour J., Abdolmalaki S., Hadavi M. 2017 - Life history traits and fishing mortality estimations of Caspian vimba, Vimba vimba (L.), in southwestern coastal regions of the Caspian Sea - Arch. Pol. Fish. 25: 145-155.

\begin{abstract}
This study was conducted to complement existing data about the life cycle of Caspian vimba, Vimba vimba (L.), with estimations of age, growth, and mortality rates. To achieve this, 811 specimens were collected between May 2012 and June 2013 at three fisheries catch stations in southwestern regions of the Caspian Sea including Talesh, Bandar Anzali, and Kiashahr. The growth rate in vimba is relatively high at approximately 0.29 year $^{-1}$ for females and 0.32 year $^{-1}$ for males. Asymptotic lengths are $245 \mathrm{~mm}$ and $233 \mathrm{~mm}$ for females and males, respectively. The growth pattern was isometric for both males and females. The overall sex ratio was balanced (1: 0.92). The instantaneous coefficients of total, natural, and fishing mortality were $1.27,0.4$, and 0.8 year, respectively, and the current exploitation ratio was 0.63 year $^{-1}$. Results showed that the growth rate of males is higher than that of females. Considering the exploitation ratio, it is apparent that the vimba population is experiencing significant legal and illegal exploitation pressure.
\end{abstract}

\footnotetext{
F. Taridashti [ $\equiv]$, J. Imanpour

Department of Fisheries, Faculty of Natural Resources University of Guilan, Sowmeh-Sara, P.O. Box. 1144, Iran e-mail: fatemetari88@gmail.com
}

\author{
S. Abdolmalaki \\ International Sturgeon Research Institute, Rasht, Guilan, P.O. Box. \\ 41635-3464, Iran \\ M. Hadavi \\ Department of Biology, Faculty of Science, University of Guilan, \\ Rasht, P.O. Box. 41335-19141, Iran
}

Keywords: Age, growth, mortality, exploitation rate, population structure, Caspian Sea

\section{Introduction}

Caspian vimba, Vimba vimba (L.), is a migratory fish with a broad distribution along the southwestern Caspian Sea (Kiabi et al. 1999). It mainly lives in fresh and brackish waters and migrates into freshwater in spring to reproduce, after which spawners return to brackish waters to feed and prepare for the next reproduction cycle (Hanfling et al. 2009). Under natural conditions, vimba attains maturity at the age of 4-5 years (Euszczek-Trojnar et al. 2008). Spawning occurs from May (Tari et al. 2015) to July on gravel beds in fast-flowing streams and rivers (Bontemps 1971).

Vimba is a commercially important species, and it has been harvested by local people for culinary purposes and recreation (Abdoli 2000). It is often caught at three years of age, and older fish are caught rarely (Abbasi et al. 2001). The population status of vimba is ambiguous since the maximum catch was recorded at 474 tons in 2009-2010 and the minimum was 9 tons in 2005-2006 (Fig. 1) (Caspian Sea Biodiversity Database 2012). These catches are primarily illegal and are

\footnotetext{
(c) Copyright by Stanisław Sakowicz Inland Fisheries Institute in Olsztyn.

(c) 2015 Author(s). This is an open access article licensed under the Creative Commons Attribution-NonCommercial-NoDerivs License (http://creativecommons.org/licenses/by-nc-nd/3.0/).
} 


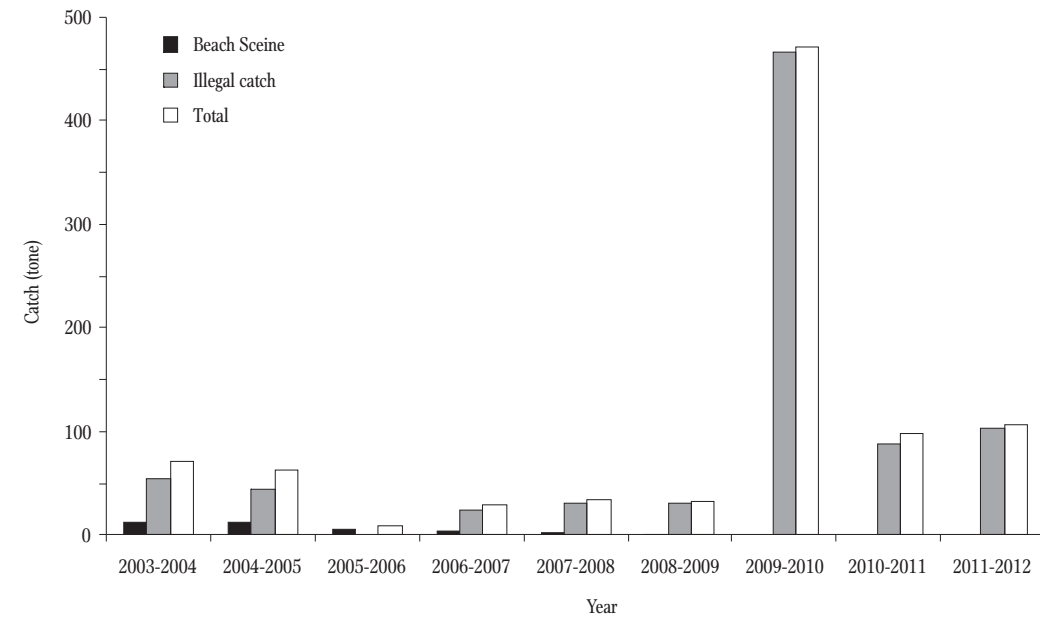

Figure 1. V. vimba catch throughout the Caspian Sea basin between 2003 and 2012.
Exploitation rates indicate the level at which a fishery is utilized. When the fishing mortality coeficient is roughly equal to natural mortality, sustainable yield is optimized (Pauly 1983).

Although previous researchers have studied the population dynamics of vimba in different parts of Caspian Sea basin (Patimar and Safari 2010, Chaichi et al. 2011, Czerniejewski et al. 2011, Okgerman et al. 2011, Rahmani et al. 2011), there is limited information on the life history traits of vimba in the southwestern coastal regions of the Caspian Sea. This is despite the widespread distribution and economic value of this

done during the spawning season in rivers flowing into the Caspian Sea. Moreover, the vimba population has declined considerably because of habitat degradation in the rivers of the southern Caspian Sea (Kiabi et al. 1999); thus, it is considered near threatened in the southern Caspian Sea basin according to IUCN criteria (Kiabi et al. 1999).

Considerable knowledge on population parameters such as age and growth is required to predict the potential yield (Lowe-McConnel 1987) and to implement the effective management of any fishery (Sarkar et al. 2012). Evaluating these parameters is important for growth rate evolution, identifying cohorts, assessing population dynamics, and determining strategies for sustainable fisheries (Rochet and Trenkel 2003). Scale analysis is used commonly to determine fish age and growth (Desai and Srivastava 1990, Tandon and Johal 1993, Sarkar et al. 2008), to analyze fishery data, and to convert growth-in-length equations to growth-in-weight in stock assessment models (Wootton 1990, Mouto-poulos and Stergiou 2002). The length-weight relationship is used extensively because of the technical difficulties and the time required to record weights in the field (Martin-Smith 1996, Sinovcic et al. 2004, Froese 2006). The condition factor provides information when comparing two populations living under specific conditions, determining gonad maturation periods, and verifying whether a species is utilizing food sources well (Sarkar et al. 2012). species. Hence, the present study work was undertaken to determine basic life history traits of vimba such as the von Bertalanfy growth parameters, age-length composition, and rates of mortality, fishing, and exploitation. All of this information is considered to be very importance for management decision making that could contribute to species conservation in the southwestern regions of the Caspian Sea.

\section{Materials and methods}

\section{Sampling regime}

A total of 811 vimba were caught incidentally by commercial fishers using gillnets with mesh sizes of 9-28 $\mathrm{mm}$ in three fishing zones that included Kiashhr ( $\left.37^{\circ} 25^{\prime} 10^{\prime \prime} \mathrm{N}, 4^{\circ} 56^{\prime} 56^{\prime \prime} \mathrm{E}\right)$, Bandar Anzali $\left(37^{\circ} 28^{\prime} 0.12^{\prime \prime} \mathrm{N}, \quad 49^{\circ} 28^{\prime} 0.12^{\prime \prime} \quad \mathrm{E}\right)$, and Talesh $\left(37^{\circ} 46^{\prime} 54.63^{\prime \prime} \mathrm{N}, 48^{\circ} 56^{\prime} 36.64^{\prime \prime} \mathrm{E}\right)$ across the southern coast of the Caspian Sea (Fig. 2) between April 2012 and June 2013 on a monthly basis. All specimens were initially preserved in iceboxes and transferred to the laboratory at the Faculty of Natural Resources, University of Guilan, Sowmeh-Sara, Iran. Sex determination was performed by gonad examination in the laboratory, and the overall sex ratio (females: males) was calculated. Fork length (FL) was measured from the tip of the snout to the extremity of the caudal fin to the nearest millimeter with a caliper. 


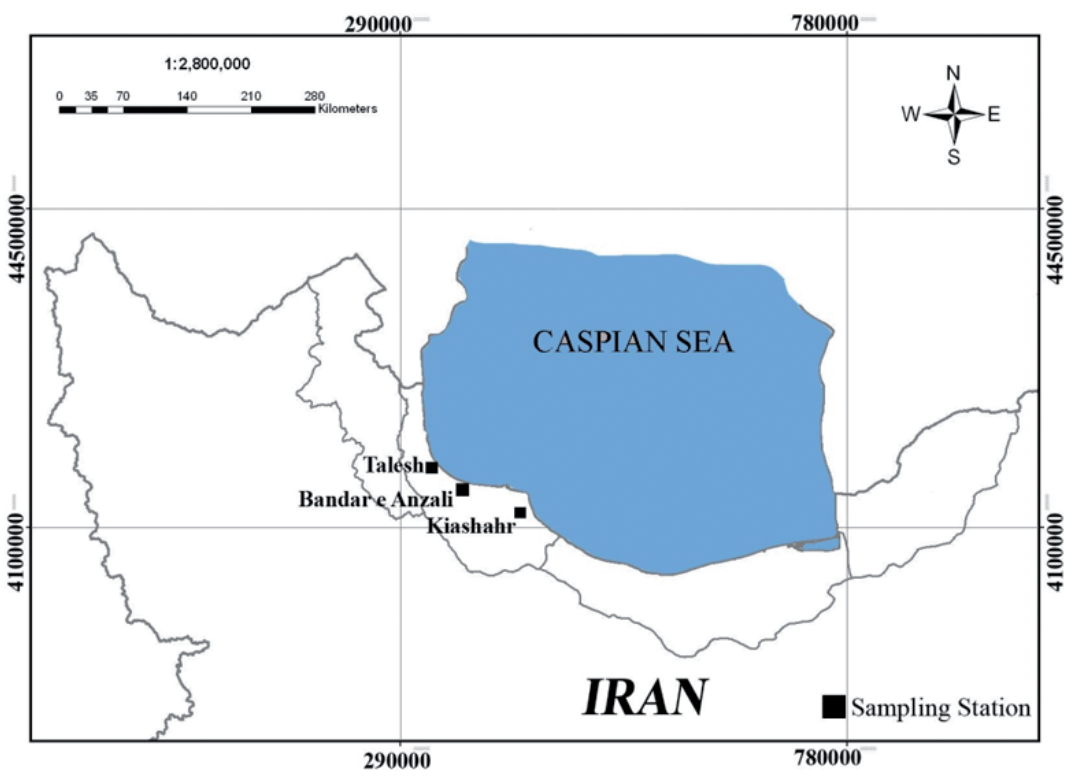

Figure 2. Map of the study area indicating sampling locations of 811 individuals including Kiashahr, Bandar Anzali, and Talesh on the southern coast of the Caspian Sea. through the nucleus were cut with a micro cutter $(400 \mu \mathrm{m})$. We processed ten pairs of otoliths, but since it was expensive and time-consuming, scales were chosen for age determination. They were removed from the area on the fish located between the lateral line and anterior edge of the dorsal fin. Extraneous matter and mucus was removed by washing the scales in tap water, then mounting them between two microscope slides, and viewing them under a stereoscopic microscope (Olympus, SZX12, USA) using transmitted light with a black background. Hyaline rings were then counted from the core out-
Total wet weight (TW) was measured to the nearest $0.1 \mathrm{~g}$ on an electronic scale after the specimen had been blot dried with a clean towel.

\section{Age determination}

To prepare vimba otoliths for age determination, they were embedded in resin, and transverse sections

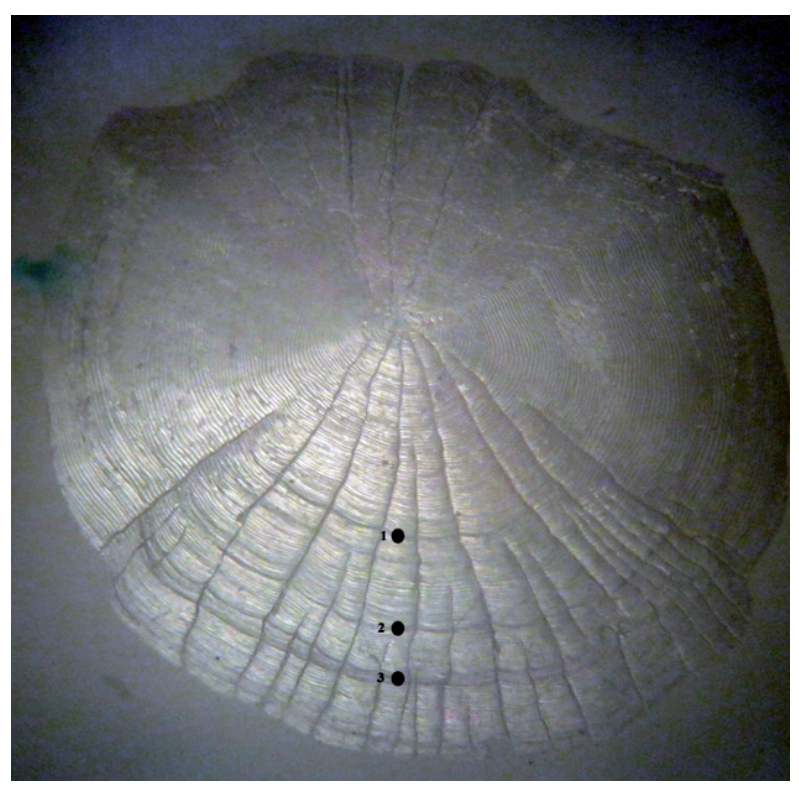

Figure 3. Scale of $V$. vimba measuring $17.1 \mathrm{~cm}$ in length aged $3^{+}$. Circles indicate annual growth bands. wards (Fig. 3). Two readers estimated ages independently, and the average percentage error (APE) was calculated as follows (Campana 2001):

$$
A P E=N^{-1} \sum_{j=1}^{N} R^{-1}\left(\sum_{i=1}^{R} \frac{|r i j-r j|}{r j}\right)
$$

where $\mathrm{N}$ is the total number of scale readings, $\mathrm{R}$ is the number of times each fish was aged, rij is the $i^{\text {th }}$ age determination for the $j^{\text {th }}$ fish, and $\mathrm{rj}$ is the mean age estimate for the $\mathrm{j}^{\text {th }}$ fish.

\section{Estimation of von Bertalanffy parameters, length-weight relationship, and condition factor}

The von Bertalanffy growth function (VBGF) parameters were estimated separately for each sex using the equation $\mathrm{Lt}=\mathrm{L}_{\infty}\left[1-\mathrm{e}^{-\mathrm{k}(\mathrm{t}-\mathrm{t} 0)}\right]$, where $\mathrm{Lt}$ is the predicted length at age $\mathrm{t}$ in $\mathrm{cm}, \mathrm{L}_{\infty}$ is the mean theoretical asymptotic length in $\mathrm{cm}, \mathrm{k}$ is a growth rate parameter in year ${ }^{-1}$, and $t_{0}$ is the theoretical age at zero length in years (Von Bertalanffy 1938). The growth performance index was estimated using the equation $\varnothing^{\prime}=\log (\mathrm{k})+2 \log \left(\mathrm{L}_{\infty}\right)$, where $\mathrm{L}_{\infty}$ and $\mathrm{k}$ are the VBGF parameters (Pauly and Munro 1984). 


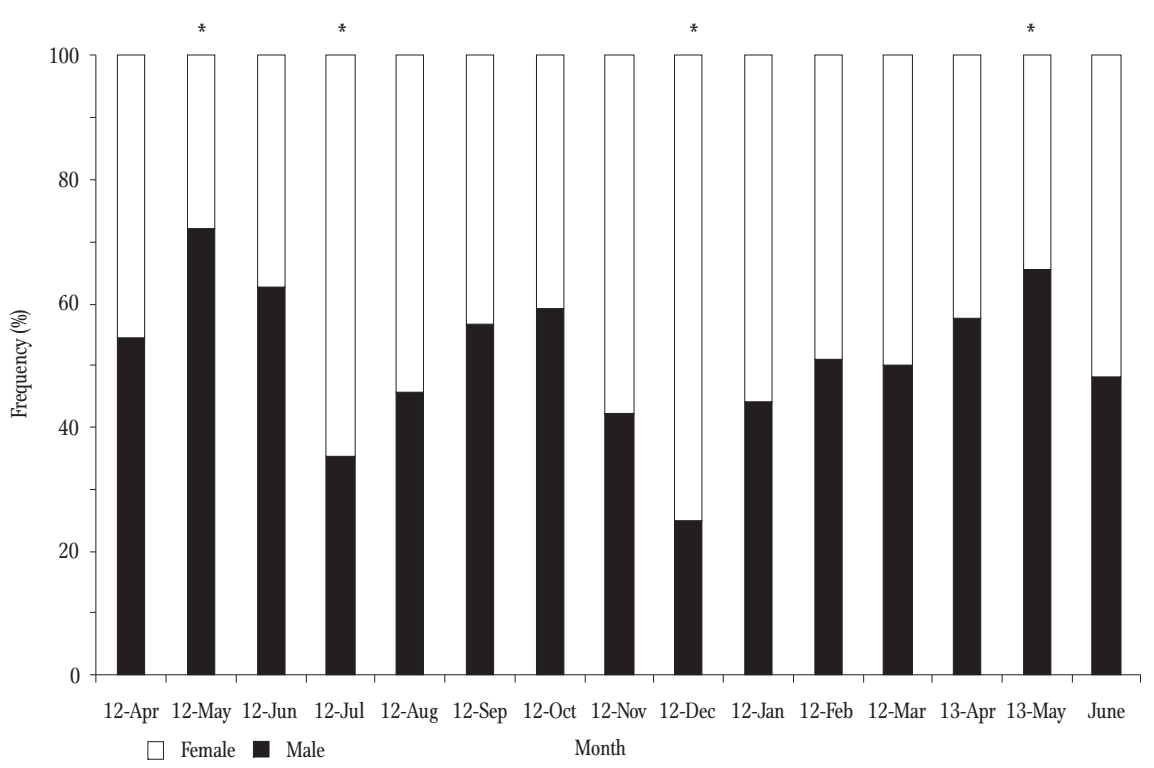

Figure 4. Monthly percentage frequency of the sexes of $V$. vimba from April 2012 to June 2013. The asterisk indicates significant differences from the theoretical 1:1 sex ratio according to the chi-square test.

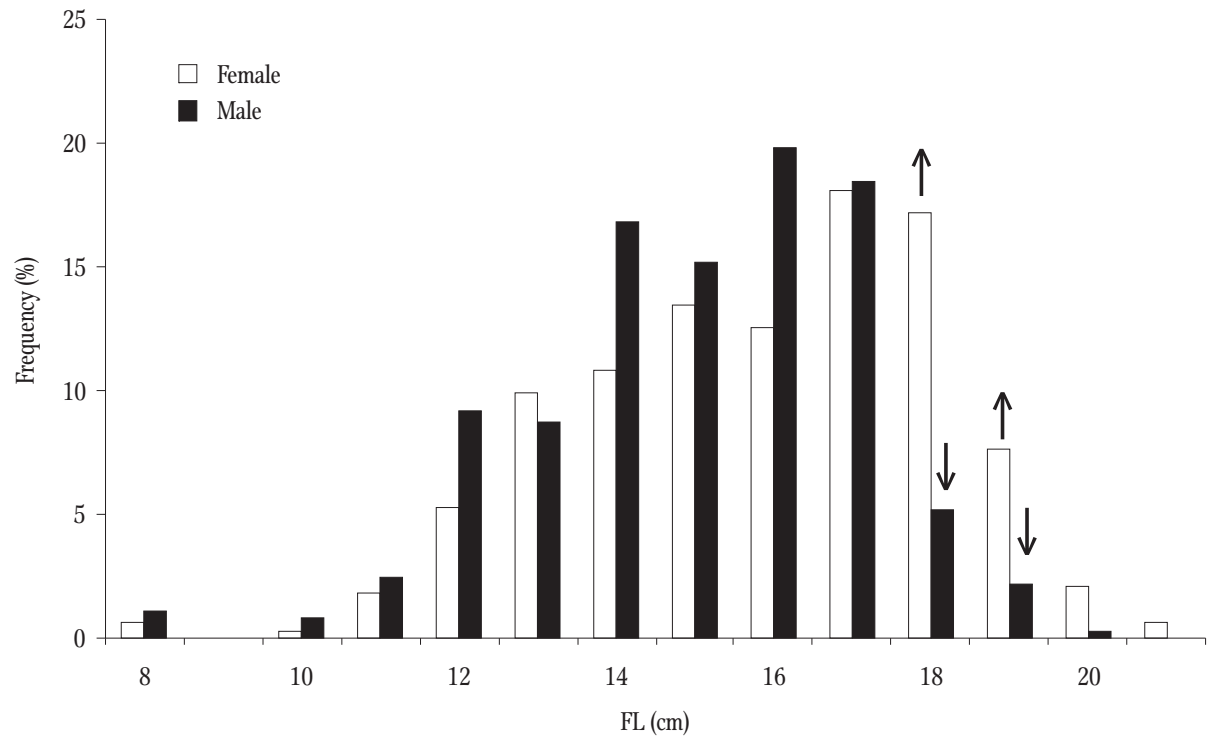

Figure 5. Fork length (FL) frequency distributions of female and male V. vimba from the southern coast of the Caspian Sea. Arrows indicate lower $(\downarrow)$ and higher $(\uparrow)$ frequency than expected.

Length-weight relationships were determined using the equation $\mathrm{TW}=\mathrm{aFL}^{\mathrm{b}}$, where $\mathrm{TW}$ is the total weight in $\mathrm{g}$, FL is the fork length in $\mathrm{cm}$, a is the intercept, and b is the slope of the regression. Fulton's condition factor was calculated with the equation $\mathrm{K}=$ $\left(\mathrm{TW} \times \mathrm{FL}^{-\mathrm{b}}\right) \times 100$, where TW is total weight in $\mathrm{g}$, FL is fork length in cm (Ricker 1975), and b is the slope of the regression obtained from the length-weight relationship.

\section{Mortality and exploitation rate}

The total mortality rate, $\mathrm{Z}$, was estimated using the linearized catch curve (King 2007). To estimate the rate of natural mortality, $\mathrm{M}$, the following method was applied (Pauly 1980):

$\operatorname{Ln}[M]=0.0066-0.279 \ln \left[L_{\infty}\right]+0.6543[K]+0.4634 \ln [T]$

where $\mathrm{T}$ is the mean temperature for the Caspian vimba habitat $\left(14^{\circ} \mathrm{C}\right.$, obtained from the Port and 

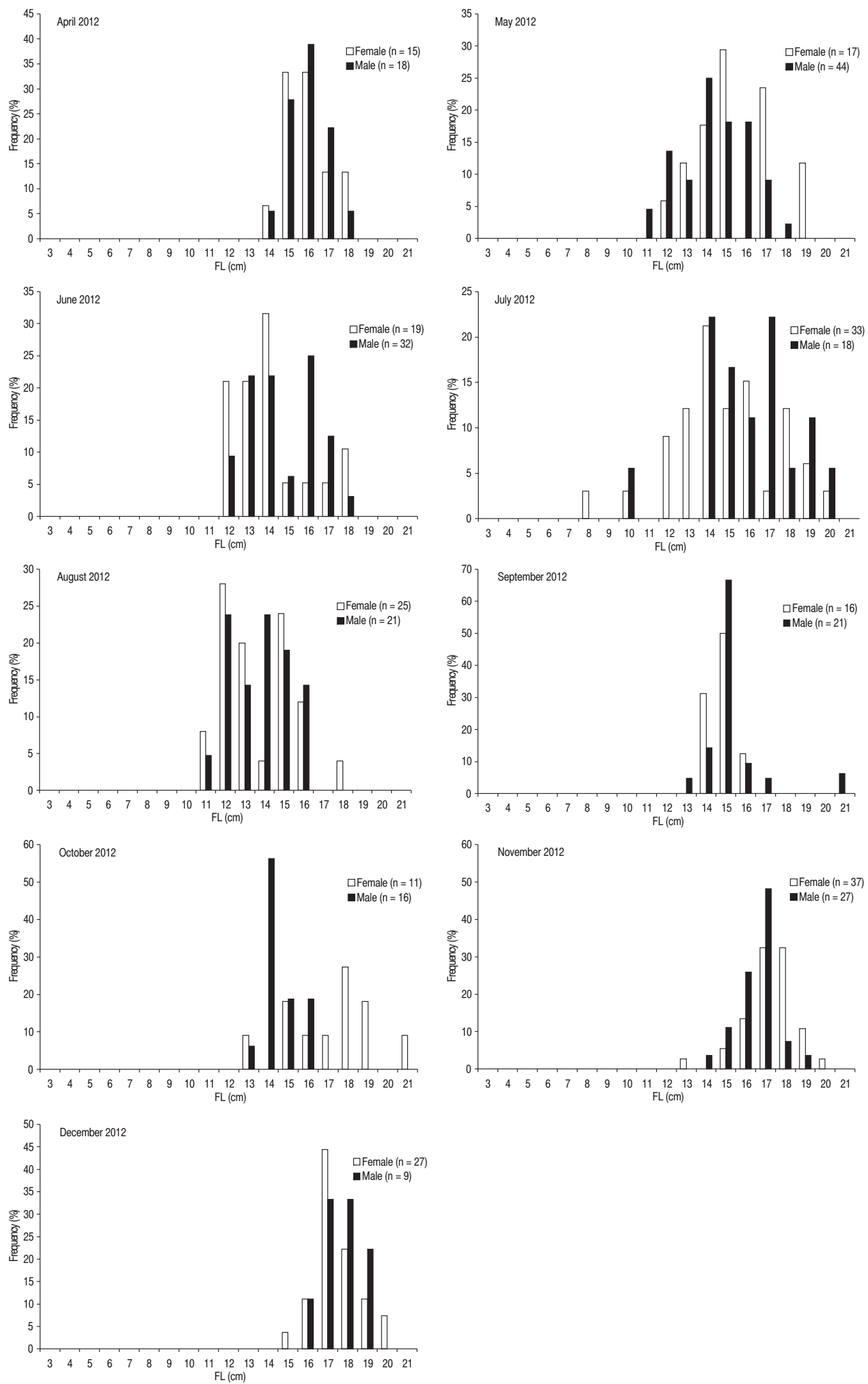

Figure 6. Monthly size distribution of $V$. vimba of females and males. 

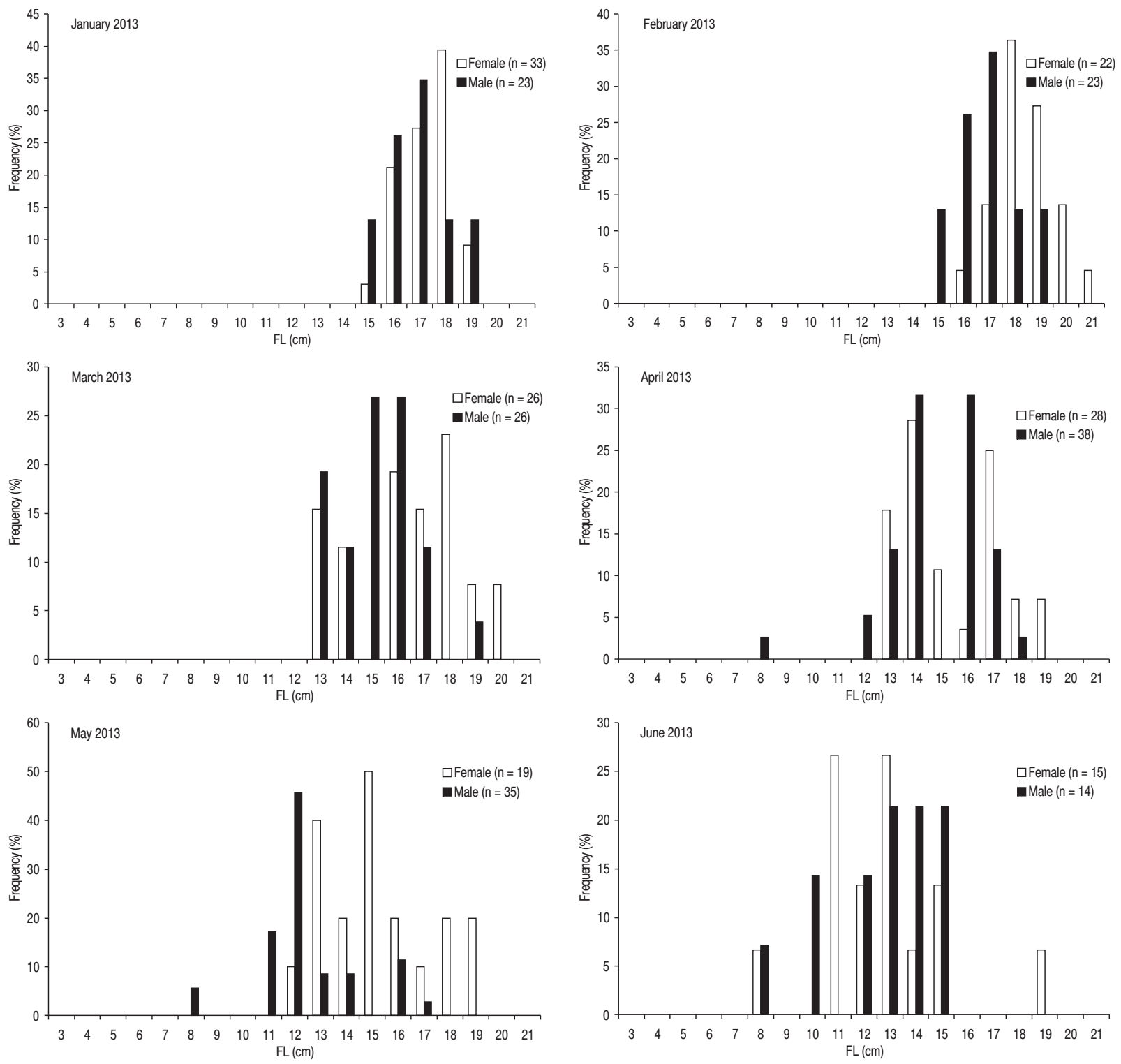

Cont. Figure 6. Monthly size distribution of $V$. vimba of females and males.

Marine Administration of Guilan Province), $\mathrm{k}$ is the growth rate parameter in year ${ }^{-1}$. The rate of fishing mortality, F, was estimated from the total mortality, F $=\mathrm{Z}-\mathrm{M}$. Exploitation rate, $\mathrm{E}$, was estimated as $\mathrm{E}=$ F/Z (Ricker 1975).

\section{Statistical analyses}

The chi-square test was used to compare the sex ratio with a 1:1 proportion. Moreover, a monthly comparison of the frequency of females and males was done using the chi-square test. Fork length and age frequency were compared between females and males with the independent chi-square test. Significant differences in von Bertalanfy parameters between females and males were evaluated with likelihood ratio tests. The slope of length-weight regression was tested against the isometric slope standard of 3 with Student's t-test. Two-way analysis of variance (ANOVA) was used to investigate the interaction effect of gender and month as independent factors on the condition factor, and Duncan's test was applied 
to determine monthly differences in genders. Statistical analyses were performed using SPSS (Version 16, Inc., Chicago, IL, USA). A significance level of 0.05 was set for data analyses. Data are presented as means \pm standard error (SE).

\section{Results}

\section{Sex ratio and size distribution}

Of the total of 811 specimen, females constituted $42.3 \%$ of the samples $(n=343)$, males constituted $45.5 \%$ of samples ( $n=369)$, and the rest of individuals were unsexed. The chi square $\chi^{2}$-test indicated that the sex ratio was not significantly different from the theoretical $1: 1$ sex ratio $\left(\chi^{2}=0.94\right.$, $\mathrm{df}=1, \mathrm{P}>$ 0.05). The frequency of males was higher than that of the females in May in both 2012 and 2013, which was the month that corresponded with the spawning season (Fig. 4). In females, fork length ranged from 8 to $24 \mathrm{~cm}$ (mean $=162, \mathrm{SE}=12)$, and in males it ranged from 8 to $20.3 \mathrm{~cm}($ mean $=153, \mathrm{SE}=10)$. As arrows in Figure 5 illustrate the frequency of females significantly outnumbered that of males in larger length classes including 18 and $19 \mathrm{~cm}\left(\chi^{2}=58.25\right.$, df
$=12, \mathrm{P}<0.05)$. Monthly size frequency distribution identified the modal lengths with cohorts in the different months, which indicated that the exploited size was between $8-21 \mathrm{~cm}$ for females and $8-20 \mathrm{~cm}$ for males (Fig. 6). The model recruitment size was between $8-9 \mathrm{~cm}$ for both females and males.

\section{Age composition}

The APE of age readings was $6.8 \%$, which showed relatively low. Of the 811 scales sampled, age ranged from $0^{+}$to $7^{+}$years. According to the figure 4 , the frequency of females is significantly more than males at $4^{+}$and $5^{+}$years $\left(\chi^{2}=33.98, \mathrm{df}=6, \mathrm{P}<0.05\right)$. More represented age was belonged to $3^{+}$years for both sexes (Fig. 7).

\section{Growth parameters, length-weight relationship, and condition factor}

The VBGF parameters were $\mathrm{L}_{\infty}=24.53 \mathrm{~cm}, \mathrm{k}=0.28$ year $^{-1}$, and $\mathrm{t}_{0}=-0.53$ years for females, and $\mathrm{L}_{\infty}=$ $23.34 \mathrm{~cm}, \mathrm{k}=0.33$ year $^{-1}$ and $\mathrm{t}_{0}=-0.29$ years for males. Likelihood ratios revealed that $\mathrm{k}$ and $\mathrm{t}_{0}$ were significantly different between the sexes $\left(\chi^{2}=42.62\right.$, $\mathrm{df}=3, \mathrm{P}<0.05$ ) (Fig. 8). The growth performance

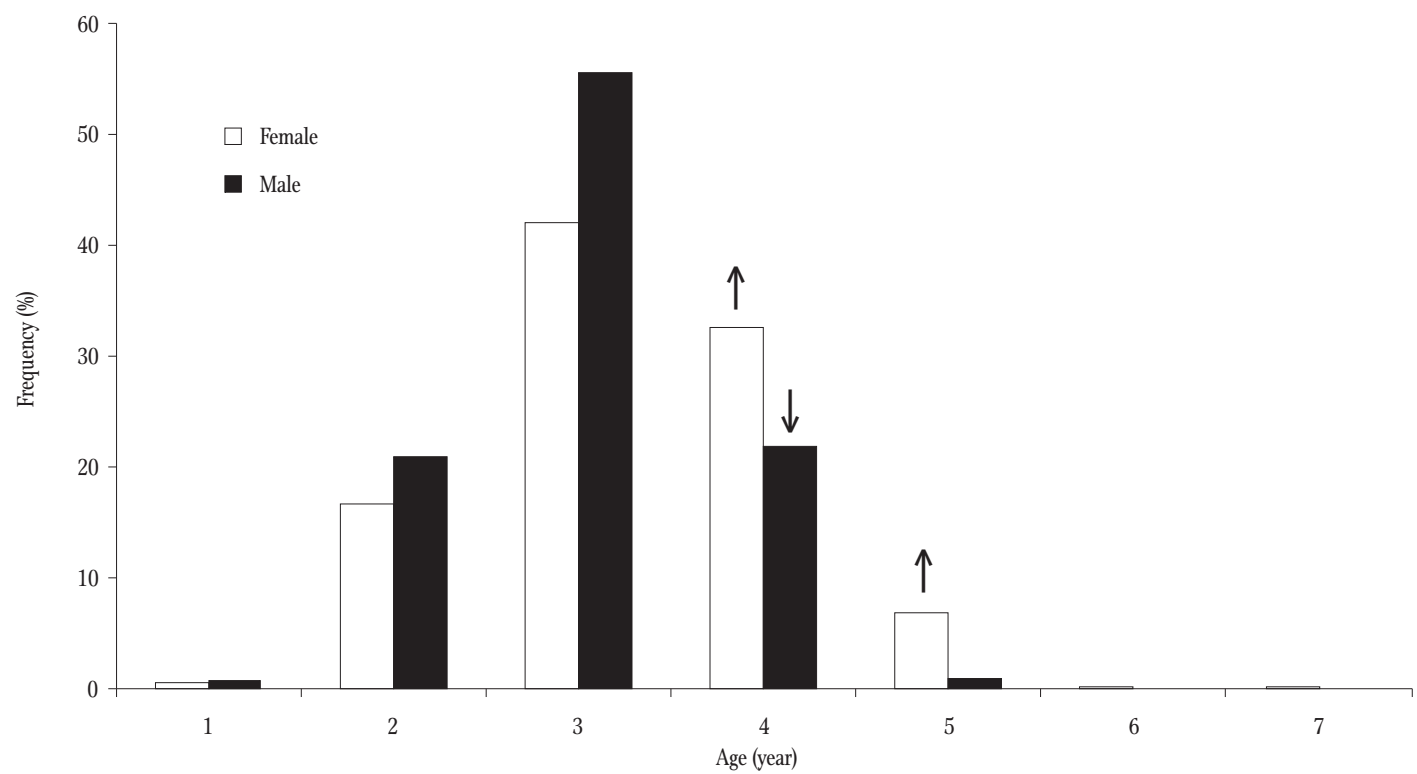

Figure 7. Age frequency distributions of female and male $V$. vimba from the southern coast of the Caspian Sea. Arrows indicate lower ( $\downarrow$ ) and higher $(\uparrow)$ frequency than expected. 


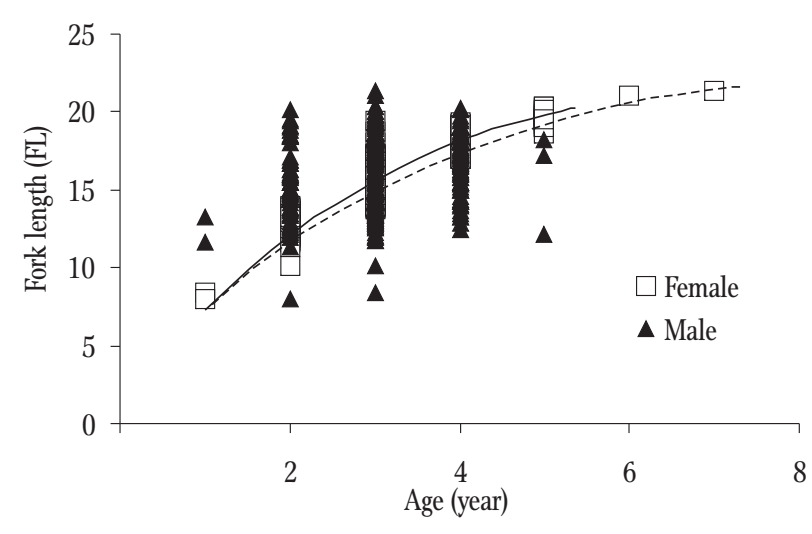

Figure 8. Growth curves fitted to observed length-at-age data for female (dashed line) and male (solid line) $V$. vimba from the southern coast of the Caspian Sea.

index $\left(\varnothing^{\prime}\right)$ was 2.25 and 2.26 for males and females, respectively. The oldest female and male were $7^{+}$ years (20.3 cm of FL) and $5^{+}$years $(21.4 \mathrm{~cm}$ of FL), respectively. The length-weight relationships were described by the equations TW $=0.0116 \mathrm{TL}^{3.023}\left(\mathrm{r}^{2}\right.$ $=0.94, \mathrm{n}=369)$ in males and TW=0.0114 $\mathrm{TL}^{3.0307}$ $\left(r^{2}=0.91, n=343\right)$ in females (Fig. 9). Considering coefficient regressions, isometric growth was revealed for both sexes $(\mathrm{P}>0.05)$. The mean variation of the condition factor for females and males was noted monthly (Fig. 10). No significant differences were observed for males $(\mathrm{F}=0.35, \mathrm{df}=13, \mathrm{P}>0.05)$; whereas considerable increases in mean the condition factor value for females was detected in June and October $(\mathrm{F}=1.70, \mathrm{df}=13, \mathrm{P}>0.05)$, which coincided with the reproductive season and the beginning of vitellogenesis.

\section{Mortality estimates}

The linearized catch curve based on age composition showed $\mathrm{Z}$ was estimated to be approximately 1.27 year $^{-1}$ for the data pool. Since ages 1-2 are not fully recruited, they were excluded from the regression line. This regression indicated that the recruitment age for the fishery was three years (Fig. 11). $\mathrm{M}$ was estimated at 0.46 year $^{-1}, \mathrm{~F}$ at 0.8 year $^{-1}$, and $\mathrm{E}$ at 0.63 year $^{-1}$ for the data pool. Mortality parameters were also calculated for males and females separately, and

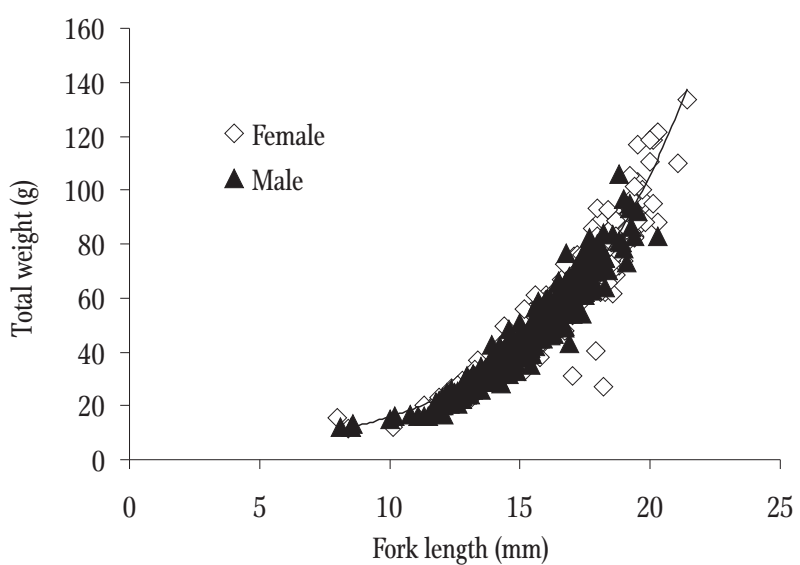

Figure 9. Length-weight relationships of female and male $V$. vimba from the southern coast of the Caspian Sea. The red line corresponds to the TL-TW relationship for the sexes combined.

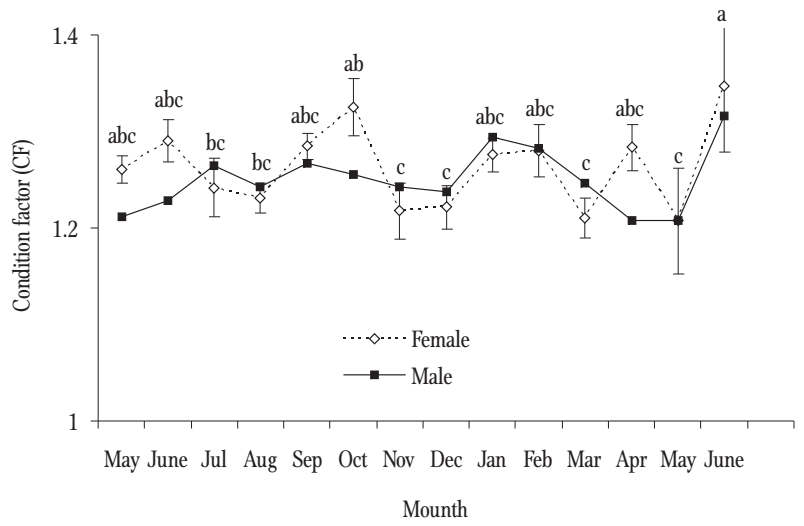

Figure 10. Condition factor for female (dashed line) and male (solid line) $V$. vimba from the southern coast of the Caspian Sea. Small letters show significant differences in the $\mathrm{K}$ value for females during the year according to Duncan's test $(\mathrm{P}<0.05)$.

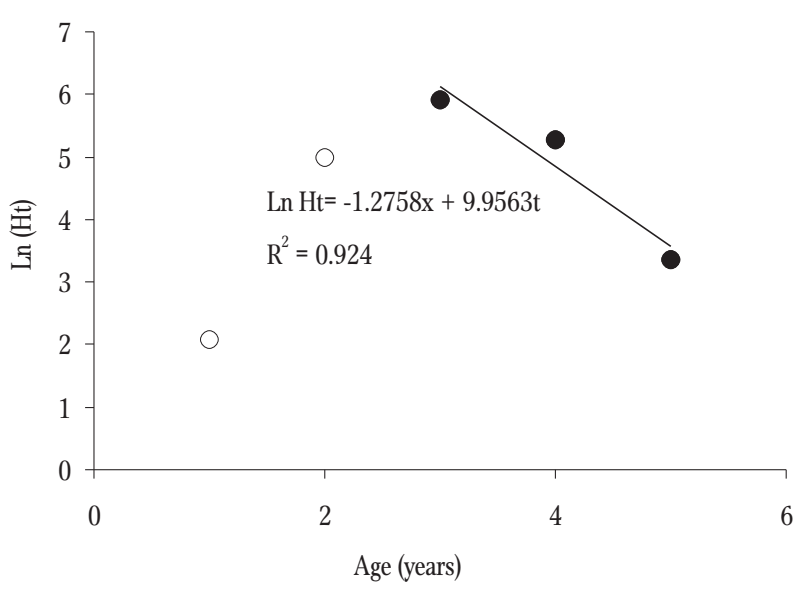

Figure 11. Linearized catch curve of $V$. vimba based on age composition showing recruitment age $3^{+}$to the fishery in the southern Caspian Sea. 
they showed different $\mathrm{Z}$ and $\mathrm{F}$ values (Table 1), with higher rates of $\mathrm{F}$ and $\mathrm{Z}$ for males.

\section{Discussion}

The estimated VBGF parameters indicated vimba exhibited different growth rates for each sex, and males had a higher $\mathrm{k}$ value but a lower $\mathrm{L}_{\infty}$ than females, which indicated that they grow faster, reached larger sizes, and lived for a shorter time than did females. The growth parameters and the age range of vimba differed in various geographical regions (Table 2). Growth rate depended on internal factors including genotype, body size, physiological condition, and external factors such as water temperature, food quality

Table 1

Mortality parameters of $V$. vimba. $\mathrm{Z}$ - total mortality, $\mathrm{M}-$ natural mortality, F - fishing mortality

\begin{tabular}{llll}
\hline \hline \multicolumn{3}{l}{ Mortality estimates } \\
\cline { 2 - 4 } & $\mathrm{M}\left(\right.$ years $\left.^{-1}\right)$ & $\mathrm{F}\left(\right.$ years $\left.^{-1}\right)$ & $\mathrm{Z}\left(\right.$ years $\left.^{-1}\right)$ \\
\hline \hline Data pool & 0.46 & 0.8 & 1.27 \\
Female & 0.60 & 0.28 & 0.89 \\
Male & 0.67 & 1.28 & 1.96 \\
\hline \hline
\end{tabular}

and availability, fishing pressure, sampling methods, and age determination (Wootton 1990). Differences in growth rates could be attributed to various geographical regions, where specific environmental conditions prevail (Ricker 1975). In our study and previous research done by Lusk et al. (2005) and Czerniejewski et al. (2011), females were dominant in older age groups, which could be related to the female growth rate. Growth rate is in reverse relation with $\mathrm{L}_{\infty}$ (Sparre and Vennema 1998), and one of the common features of Cyprinids is that the growth rate of females is lower than that of males (Abdoli 2000), which means the females live longer than the males and are present in older age groups.

The condition factor reflects the physiological state of a fish in relation to its welfare through variations (Le Cren 1951). It is based on the hypothesis that heavier individuals of a given length are in better condition (Bagenal and Tesch 1978). Analyses of vimba length-weight relationships showed that female vimba presented the highest condition values in April and June. As the fishing season advanced and migration proceeded, condition factor value decreases. According to Hoseini-Kenari et al. (2010), vimba starts river-bound reproduction migration

Table 2

Growth parameters and age range of $V$. vimba in various geographical regions. $\mathrm{L}_{\infty}$ - theoretical maximum length (cm), $\mathrm{K}$ is a constant expressing the rate of approach to $\mathrm{L}_{\infty}$.

\begin{tabular}{|c|c|c|c|c|c|c|}
\hline Authors & Present study (2017) & $\begin{array}{l}\text { Patimar and Safari } \\
(2010)\end{array}$ & Chaichi et al. (2011) & $\begin{array}{l}\text { Okgerman et al. } \\
\text { (2011) }\end{array}$ & $\begin{array}{l}\text { Czerniejewski et al. } \\
\text { (2011) }\end{array}$ & $\begin{array}{l}\text { Lusk et al. } \\
(2005)\end{array}$ \\
\hline Area & $\begin{array}{l}\text { Southwestern coast } \\
\text { of Caspian Sea }\end{array}$ & $\begin{array}{l}\text { Southeastern coast } \\
\text { of Caspian Sea }\end{array}$ & $\begin{array}{l}\text { Southern coast } \\
\text { of Caspian Sea }\end{array}$ & $\begin{array}{l}\text { Northern Anatolia, } \\
\text { Turkey }\end{array}$ & Odra River estuary & River Dyje \\
\hline \multicolumn{7}{|l|}{$\mathrm{L}_{\infty}$} \\
\hline Female & 24.53 & 35.95 & - & 24.70 & - & - \\
\hline Male & 23.34 & 32.56 & - & 28.94 & - & - \\
\hline Data pool & - & - & 26.1 & - & - & - \\
\hline \multicolumn{7}{|l|}{ K } \\
\hline Female & 0.28 & 0.17 & - & 0.20 & - & - \\
\hline Male & 0.33 & 0.18 & - & 0.12 & - & - \\
\hline Data pool & - & - & 0.28 & - & - & - \\
\hline \multicolumn{7}{|l|}{ Age } \\
\hline Female & $1^{+}-7^{+}$ & $2^{+}-5^{+}$ & $1^{+}-5^{+}$ & $2^{+}-6^{+}$ & $3^{+}-11^{+}$ & $4^{+}-10^{+}$ \\
\hline Male & $1^{+}-5^{+}$ & $2^{+}-5^{+}$ & $1^{+}-5^{+}$ & $2^{+}-6^{+}$ & $3^{+}-11^{+}$ & $3^{+}-7^{+}$ \\
\hline Data pool & $1^{+}-7^{+}$ & $2^{+}-5^{+}$ & $1^{+}-5^{+}$ & $2^{+}-6^{+}$ & $3^{+}-11^{+}$ & $3^{+}-10^{+}$ \\
\hline
\end{tabular}


from the Kiashahr coasts in March, and its peak was observed in June. We interpreted the lower condition factor value as indicative of the end of reproduction. An increase in the condition value was observed in October, which could be related to the onset of vitellogenesis.

The results of this study indicated that the sex ratio was not statistically different from the theoretical 1:1 sex ratio, which concurs with previous studies (Pauly 1980, Abbasi et al. 2001). Previous studies in the southeastern Caspian Sea and Dyje River show that vimba populations are dominated by males (Lusk et al. 2005, Rahmani et al. 2011). Differences in sampling time and methods can influence the sex ratio. Earlier studies on vimba report a female-dominated sex ratio (Chaichi et al. 2011, Czerniejewski et al. 2011). This could stem from higher frequencies of older age classes in their samples. Males are generally dominant in younger age classes, and as the individuals age the sex ratio shifts to female domination (Nikoliskii 1963, Potts and Wootton 1990, Inversen 1996). We confirmed that specimens at aged $3^{+}$are recruited to the fishery since they are undergoing reproductive migration. In the southern Caspian Sea, Chaichi et al. (2011) found the length at first maturation to be $17 \mathrm{~cm} \mathrm{FL}$ for females, which translates to and age of $3^{+}-4^{+}$.

Mortality parameters including $\mathrm{F}$ and $\mathrm{Z}$ were higher in males than in females, while $\mathrm{M}$ did not differ between the sexes. This supports our findings that males with higher a $\mathrm{k}$ value grow faster and live shorter than do females. In the present study, E was computed at 0.63 . An $\mathrm{E}$ value of greater than 0.5 indicates overexploitation according to the Pauly (1980) method for estimating M. Reducing the fishing effort is one of the best ways to control and manage exploitation rates (Jenning et al. 2000). With reference to vimba targeted by illegal catches and poaching, rather than legal overfishing, urgent measures are indispensable for controlling catch and exploitation rates.

This study permits us to conclude that vimba has an estimated life span of six years, reaches up to 24.5 $\mathrm{cm}$ in FL, and has fast growth rates $\left(\mathrm{k}=0.29\right.$ years $^{-1}$ for males, and $\mathrm{k}=0.32$ years $^{-1}$ for females). At the age of $3^{+}$vimba were fully recruited and participated in reproduction. Exploitation rates showed values greater than 0.5 based on preliminary estimations. In summary, the results of this study will help to improve stock assessments of vimba populations in the southwestern regions of the Caspian Sea, which will provide a foundation for effective stock management.

Acknowledgments. The authors would like to thank the staff of the Inland Water Aquaculture Research Institute, Guilan, Iran, for their support. Some parts of the present research were supported financially by the University of Guilan.

Author contributions. F.T. performed the experiment, and wrote the paper; J.I. provided financial support, and revised manuscript; S.A. designed the experiment, and analyzed the data; M.H. did the laboratory procedure.

\section{References}

Abbasi K., Moradi M., Ramezani M., Valipour A., Mahiseffat F. 2001 - Investigation of the reproduction of anaderamos fish in Sefidroud river - Iranian Fishery Research Institute Publications, Tehran, 166 p. (in Persian).

Abdoli A. 2000 - The inland water fishes of Iran - Iranian Museum of Nature and Wildlife Press, Tehran, Iran, 377 p. (in Persian)

Bagenal T.B., Tesch F.W. 1978 - Age and growth - In: Methods for assessment of fish production in fresh waters (Ed.) T. Begenal, IBP Handbook, Blackwell Science Publications, Oxford, London, UK, 101-136.

Bontemps S. 1970 - Vimba - PWRiL, Warsaw, Poland. 216 p. (in Polish).

Campana S.E. 2001 - Accuracy, precision and quality control in age determination, including a review of the use and abuse of age validation methods - J. Fish Biol. 59: 197-242.

Caspian Sea Biodiversity Database. 2010 http://www.caspianenvironment.org - Cited November 1.

Chaichi A.R., Vosoughi G.H., Kaymaram F., Jamili S., Fazli H. 2011 - Reproduction characteristics of the Vimba vimba persa (Pallas, 1811) in coastal waters of the Caspian Sea - Iran. J. Fish. Sci. 10: 585-595.

Czerniejewski P., Rybczyk A., Tanski A., Keszka S., Antoszek A. 2011 - Growth rate and condition of vimba, Vimba vimba (Actinopterygii: Cypriniforms: Cyprinidae), a species under restitution in the Odra River estuary - Acta Ichtyol. Pisc. 41: 215-222. 
Desai V.R., Srivastava N.P. 1990 - Studies on age, growth and gear selectivity of Cirrhinus twigala (Hamilton) from Rihand reservoir, Uttar Pradesh - Ind. J. Fish. 37: 305-311.

Froese R. 2006 - Cube law, condition factor and weight-length relationships: history, meta-analysis and recommendations - J. Appl. Ichthyol. 22: 241-253.

Hanfling B., Dumpelmann C., Bogutskaya N.G., Brandl R., Brandle M. 2009 - Shallow phylogeographic structuring of Vimba vimba across Europe suggests two distinct refugia during the last glaciations - J. Fish Biol. 75: 2269-2286.

Hosseini-Kenari S.M., Alam M., Ardalan A.A., Behnaz M. 2010 - Study on biology of reproduction in Vimba vimba (L. 1758) in Kiashahr region - J. Fish. 4: 47-61 (in Persian).

Inversen E.S. 1996 - Living marine resource (their utilization \& management) - Chapman and Hall, London, UK: 403 p.

Jenning S., Kasier M., Reynold J. 2000 - Marine Fisheries Ecology - Black wall Science: 391 p.

Kiabi B.H., Abdoli A., Naderi M. 1999 - Status of fish fauna in the South Caspian Basin of Iran - J. Zool. Mid. East. 18: 57-65.

King M. 2007 - Fisheries Biology, Assessment and management, 2nd edition - Blackwell Scientific Publication, Australia: $382 \mathrm{p}$.

Le Cren E.D. 1951 - The length-weight relationship and seasonal cycle in gonad weight and condition in the perch (Perca fluviatilis) - J. Anim. Ecol. 20: 201-218.

Lowe-McConnel, R.H. 1987 - Ecological Studies in Tropical Fish Communities - Cambridge University Press, London, UK: 382 p.

Lusk S., Luskova V., Halacka K., Slechtova V., Slechta V. 2005 Characteristics of the remnant Vimba vimba population in the upper part of the Dyje River - Folia Zool. 54: 389-404.

Łuszczek-Trojnar E., Drag-Kozak E., Kleszcz M., Popek W., Epler P. 2008 - Gonadal maturity in vimba (Vimba vimba L) raised in carp ponds - J. Appl. Ichthyol. 24: 316-320.

Martin-Smith K.M. 1996 - Length -weight relationships of fishes in a diverse tropical fresh-water community, Sabah, Malaysia - J. Fish Biol. 49: 731-734.

Moutopoulos D.K., Stergiou K.I. 2002 - Length-weight and length-length relationships of fish species from the Aegean Sea (Greece) - J. Appl. Ichthyol. 18: 200-203.

Nikoliskii G.V. 1963 - Ecology of Fishes - Academic Press, London, UK: 352 p.

Okgerman H., Elp M., Yardimci C.H. 2011 - Growth, the length-weight relationship, and reproduction in Vimba (Vimba vimba L. 1758) sampled from an oligo-mesotrophic lake in northwest Anatolia (Turkey) - Turk. J. Zool. 35: 87-96.

Patimar R., Safari S. 2010 - Description of the biology of Caspian vimba, Vimba vimba (Linnaeus, 1758) in Gorgan Bay-Miankale Wildlife Refuge (Southeast Caspian Sea) Chin. J. Oceanol. Limnol. 28: 1173-1179.
Pauly D. 1980 - On the interrelationships between natural mortality, growth parameters, and mean environmental temperature in 175 fish stocks - Int. Coun. Expl. Sea. 39: 175-192.

Pauly D. 1983 - Some simple methods for assessment of tropical fish stock - FAO Fisheries Technical Paper: 234: 52 p.

Pauly D., Munro J.L. 1984 - Once more on the comparison of growth fish and invertebrates - Fishbyte 2: $21 \mathrm{p}$.

Potts G.W., Wootton R.J. 1990 - Fish reproduction strategies and tactics - Academic Press Limited: 410 p.

Rahmani H., Kiabi B.H., Abdoli A. 2011 - Age, Growth and Reproduction Characteristics of Vimba vimba persa in South-East of Caspian Sea (Iran) - J. Fish. Int. 6: 46-51.

Ricker W.E. 1975 - Computation and interpretation of biological statistics of fish populations. Department of Environment, Fisheries and Marine Service, Ottawa: $382 \mathrm{p}$.

Rochet M.J., Trenkel V.M. 2003 - Which community indicators can measure the impact of fishing? A review and proposals - Can. J. Fish. Aqua. Sci. 60: 86-99.

Sarkar U.K., Kumar R.S., Dubey V.K., Pandey A., Lakra W.S. 2012 - Population structure and reproductive biology of a freshwater fish, Labeo boggut (Sykes, 1839), from two perennial rivers of Yamuna basin - J. Appl. Ichthyol. 8: 107-115.

Sarkar U.K., Negi R.S., Deepak P.K., Lakra W.S., Paul S.K. 2008 - Biological parameters of endangered Chitala chitala (Osteoglossiformes: Notopteridae) from some Indian rivers - Fish. Res. 90: 170-177.

Sinovcic G., Franicevic M., Zorica B., Cikes-Kec V. 2004 Length-weight and length-length relationships for 10 pelagic fish species from the Adriatic Sea (Croatia) - J. Appl. Ichthyol. 20: 156-158.

Sparre D., Venema S.C. 1998 - Introduction to tropical fish stock assessment, Part 1, Manual - FAO Fisheries Technical Publication: 376 p.

Tandon K.K., Johal M.S. 1993- Characteristics of larval marks and origin of radii - Int. J. Curr. Sci. 64: 524-526.

Tari F., Namin J.I., Abdolmalaki S., Hadavi M. 2015 Reproductive biology of Caspian vimba, Vimba vimba (L.), in the coastal waters of the southwestern Caspian Sea - Arch. Pol. Fish. 23: 171-180.

Von Bertalanffy L. 1938 - A quantitative theory of organic growth (inquiries on growth laws II) - Human Biol. 10: 181-213.

Wootton R.J. 1990 - Ecology of teleost fishes - Chapman and Hall, London, UK: 404 p. 